\title{
Presence of the cytolytic protein enterolobin in different developmental stages of Enterolobium contortisiliquum seeds
}

\author{
Consuelo M. R. de Lima*, Pedro J. P. Zanotta, Carlos A. O. Ricart and Marcelo V. de Sousa \\ Brazilian Center for Protein Research, Department of Cell Biology, University of Brasília, 70910-900 Brasília, DF, \\ Brazil.*Corresponding author: consuelo@unb.br
}

Received: 29 March 2007; Returned for revision: 21 June 2007; Accepted: 03 September 2007

Enterolobin is a $52.9 \mathrm{kDa}$, cytolytic, inflammatory and insecticidal protein present in Enterolobium contortisiliquum (Vell.) Morong, a Brazilian large-sized tree. This protein was previously described to occur in different forms of association (monomeric and oligomeric forms). In the current work, we investigated the presence of enterolobin forms of association and hemolytic activity in maturing, germinating and germinated seeds. Immunoblotting analysis revealed the presence of the monomeric form of enterolobin in all phases under study, whereas the dimer was detected in developing seeds in the second half of the maturation period, during germination and in the early post-germination phase. The trimeric form of enterolobin appeared one week after the dimer and could be detected up to half of the average germination time of the E. contortisiliquum seeds. The highest hemolytic titers due to enterolobin activity were found in mature and germinating seeds. Apparently, there was no modification in molecular mass of the enterolobin monomer during seed maturation and germination, suggesting the absence of a precursor form. The results also show that enterolobin was not utilized in germination and initial post-germination phases, which are critical in development and seedling establishment. Enterolobin availability could enable it to perform an important physiological role, including plant defense.

Key words: defense proteins, hemolytic proteins, plant defense, seed germination

Presença da proteína citolítica enterolobina em diferentes estágios de desenvolvimento de sementes de Enterolobium contortisiliquum: Enterolobina, uma proteína de 52,9 kDa, apresenta atividades citolítica, inflamatória e inseticida, sendo encontrada em Enterolobium contortisiliquum (Vell.) Morong, uma árvore brasileira de grande porte. Relatos anteriores descrevem a ocorrência dessa proteína em diferentes formas de associação (formas monomérica e oligoméricas). No presente trabalho, foi investigada a presença de formas de associação da enterolobina e atividade hemolítica em sementes maturescentes, germinantes e germinadas. A análise por immunoblotting revelou a presença da forma monomérica da enterolobina em todas as fases investigadas, enquanto o dímero foi detectado nas sementes em desenvolvimento na segunda metade do período de maturação, durante a germinação e no período inicial pósgerminativo. A forma trimérica da enterolobina foi detectada desde uma semana após o dímero até a metade do tempo médio de germinação da semente de E. contortisiliquum. O mais alto título de atividade hemolítica devido à enterolobina foi encontrado em sementes maduras e germinantes. Aparentemente, não houve alteração da massa molecular do monômero de enterolobina durante a maturação e a germinação da semente, sugerindo a ausência de uma forma precursora. Os resultados também mostram que a enterolobina não foi utilizada na germinação e na fase inicial de pósgerminação, que são críticas no desenvolvimento e estabelecimento da plântula. Contudo, a disponibilidade de entorolobina poderia capacitá-la a exibir um importante papel fisiológico, incluindo o de defesa da planta.

Palavras-chave: defesa da planta, germinação de semente, proteínas de defesa, proteínas hemolíticas 


\section{INTRODUCTION}

In the early stages of seed development, the zygote originates a multicellular embryo by division and differentiation. These events, collectively known as histodifferentiation, are characterized by a rapid increase in both fresh weight and water content of the seeds. A period of synthesis of reserve substances follows, with further increase in the weight accompanied by cellular expansion to accommodate reserves. As the insoluble reserves increase, the water content of the seeds decreases. The rate of water loss asymptotically approaches zero during seed maturation (Bewley and Black, 1994).

The majority of mature seeds contain at least two or three main reserve substances (carbohydrates, lipids and proteins) in significant amounts, which are utilized during seed germination and establishment of the seedlings. During these stages a rapid degradation of reserve proteins (RP) is observed (for reviews, Shewry, 1995; Müntz, 1996). These proteins comprise a significant part of the seed's proteins and provide nitrogen, sulfur and carbon for the young seedling. Synthesis and deposition of RPs in mono and dicotyledons use very complex and diversified mechanisms (Hershko and Ciechanover, 1992; Vierstra, 1993). There is a universal degradation pattern for different RPs. Generally, they suffer limited proteolysis producing fragments of different sizes that are rapidly processed to free amino acids, and utilized by the seedling (Fincher, 1989; Hershko and Ciechanover, 1992; Vierstra, 1993; Müntz, 1996).

Plants have developed several defense systems based on structural obstacles and metabolic processes. In general, the response to an aggressor agent is complex and involves many factors. There are two basic types of plant defense, constitutive and inducible, but the response, usually, depends on both. Many proteins and peptides, including enzyme inhibitors, lectins and thionins, have been described as related to plant defense (Shewry and Lucas, 1997; Cuadrado et al., 2000; Muzquiz et al., 2004).

Enterolobin, a $52.9 \mathrm{kDa}$, hemolytic, inflammatory, cytotoxic and insecticidal protein obtained from $E$. contortisiliquum seeds (in vitro activities), has been extensively characterized (Sousa and Morhy, 1989; Sousa et al., 1990; Sousa et al., 1993; Fontes et al., 1997). Some studies utilizing gel filtration, SDS-PAGE, immunoblotting, mass spectrometry and atomic force microscopy (Fontes et al., 1997; Lima, 1999; Lima et al., 1999; Bittencourt et al., 2003) revealed that enterolobin occurs in different forms of association (monomeric and oligomeric) similar to those described for aerolysins, pore-forming toxins from Aeromonas bacteria. Enterolobin and aerolysin were shown to share amino acid sequence, tertiary structure and functional similarities (Sousa et al., 1994; Fontes et al., 1997; Bittencourt et al., 2003). Aerolysin is exported to the culture medium as a protoxin (an inactive precursor form), which is later activated by specific proteolysis (Howard and Buckley, 1985), but so far it has not been established if enterolobin suffers a similar processing.

Although much is known about enterolobin structure and in vitro activities, few studies have been carried out concerning its physiological and biochemical roles in the plant (Lima, 1999; Lima et al., 1999). In order to shed some light on these aspects, the present work aimed to investigate the expression of enterolobin, by monitoring its hemolytic activity or immunodetection (or both), including changes in the degree of oligomerization and in the molecular mass of the monomeric form. Thus the presence of enterolobin was investigated during seed maturation, germination and in the early post-germinative stages (up to 10 days).

\section{MATERIAL AND METHODS}

Plant material: Enterolobium contortisiliquum seeds were obtained from maturing and mature legumes in the region of Brasília (Federal District, Brazil). Voucher branches with leaves, flowers and fruits were deposited in the Herbarium of the University of Brasilia. Plant material was harvested weekly during a period of approximately four months (from June, 23 to October, 07) corresponding to the interval between the appearance of the earliest green legumes and legume maturation. The seeds were manually removed from the legumes, and the tegument removed, except in the case of those mature seeds used for the germination assay (see below). The naked seeds were stored at $-80^{\circ} \mathrm{C}$ until use. The seeds utilized in this study were stored for no longer than one year after harvesting. The degree of seed maturation was 
based on the estimated water content of the seeds as described by Lima et al. (1997), assuming that the hydration degree inversely correlates with dry matter content.

Experimental design: In order to obtain germinating and post-germinated seeds an experimental strategy was delineated using as reference the average $E$. contortisiliquum germination time $\left(\mathrm{t}_{\mathrm{m}}=42.45 \mathrm{~h}\right.$ at $\left.30.3^{\circ} \mathrm{C}\right)$, as determined by Lima et al. (1997). A sample of 700 mature E. contortisiliquum freshly harvested seeds was chemically scarified using commercial sulphuric acid for 1 $\mathrm{h}$, under stirring, exhaustively washed with distilled water, and left to germinate. Sets of 15 germinating seeds were collected at intervals based on $\mathrm{t}_{\mathrm{m}}$ as follows: $0.125 \mathrm{t}_{\mathrm{m}}$ $(5.3 \mathrm{~h}), 0.25 \mathrm{t}_{\mathrm{m}}(10.6 \mathrm{~h}), 0.5 \mathrm{t}_{\mathrm{m}}(21.22 \mathrm{~h}), 0.75 \mathrm{t}_{\mathrm{m}}(31.84 \mathrm{~h}), \mathrm{t}_{\mathrm{m}}$ $(42.45 \mathrm{~h}), 1.125 \mathrm{t}_{\mathrm{m}}(47.76 \mathrm{~h}), 1.25 \mathrm{t}_{\mathrm{m}}(53.1 \mathrm{~h})$, and $1.5 \mathrm{t}_{\mathrm{m}}$ (63.67 h).

At $t_{\mathrm{m}}$, about 250 of just germinated seeds (according to the botanical criterion) were set apart. A group of 15 seeds of this set was collected and processed as described below. The remaining seeds were maintained in the incubation system and a group of 15 post-germinated seeds were collected daily until the $10^{\text {th }}$ day (i.e. from 1 to $10 \mathrm{~d}$ after $\mathrm{t}_{\mathrm{m}}$ ). After each sampling the tegument was removed and the naked seeds processed (see below). There were no replicates for any of these samples.

The processing of all naked seed samples, including maturing and mature ones (those harvested from June to October), involved immersing them in liquid nitrogen followed by grinding. The resulting powders were stored at $-20^{\circ} \mathrm{C}$. To verify if the scarification treatment with sulphuric acid affected the electrophoretic protein profile of the seeds, 15 non-chemically scarified seeds were used, and compared with 15 seeds scarified with sulfuric acid.

Soluble fraction preparation: All seed powder samples were extracted at $4^{\circ} \mathrm{C}$ for 30 min under stirring using a ratio of $1 \mathrm{~g}$ of powder per $8 \mathrm{~mL}$ of phosphate buffered saline (PBS) (20 mmol NaH $\mathrm{PO}_{4} \mathrm{~L}^{-1}$ at $\mathrm{pH} 7.2,0.13 \mathrm{~mol} \mathrm{NaCl}$ $\mathrm{L}^{-1}, 1$ mmol EDTA L ${ }^{-1}$ ). Phenylmethylsulphonylfluoride (PMSF), tosyllysilchloroketone (TLCK) and dithiothreitol (DTT) (1 mmol $\left.\mathrm{L}^{-1}\right)$ plus $1 \%$ (w/v) polyvynilpolypyrrolidone (PVPP) were added just before extraction. The crude extracts were centrifuged at 40,000 g for $1 \mathrm{~h}$ at $4^{\circ} \mathrm{C}$, and the supernatants were ultra-centrifuged at $100,000 \mathrm{~g}$ for $1 \mathrm{~h}$ at $4^{\circ} \mathrm{C}$ (Lima, 1999). The resulting supernatants were denominated Soluble Fractions (SF), that were numbered as follows: SF 1 to 11 refer to maturing seeds collected from 14 to 1 weeks before maturation; SF 12 and 13 refer to mature seeds (non scarified and scarified seeds, respectively); SF 14 to 21 refer to germinating seeds (from $0.125 \mathrm{t}_{\mathrm{m}}$ to $1.5 \mathrm{t}_{\mathrm{m}}$ ); $\mathrm{SF} 22$ refers to freshly germinated seeds and SF 23 to 32 refer to post-germinated seeds (from 1 to $10 \mathrm{~d}$ ).

Hemolytic assay: The presence of hemolytic activity in each SF was assessed by incubation with a $3 \%$ erythrocyte suspension for $1 \mathrm{~h}$ at RT. Aliquots of the samples were pre-incubated at $65^{\circ} \mathrm{C}$ for $1 \mathrm{~h}$ and then assayed for hemolytic activity. Those SF that lost the hemolytic activity upon heating had their hemolysis titer determined (Sousa and Morhy, 1989). Aliquots of $50 \mu \mathrm{L}$ of each SF were twofold serially diluted in PBS followed by incubation with the same volume of an $\mathrm{O}^{+}$red blood cells suspension (3\% v/v in $\left.\mathrm{NaCl} 0.15 \mathrm{~mol} \mathrm{~L}^{-1}\right)$. After $1 \mathrm{~h}$, the results were recorded and the hemolytic titer was considered to be the inverse of the highest dilution still presenting hemolysis. The hemolytic titer of a purified enterolobin (Lima et al., 1999) solution, at $0.5 \mu \mathrm{g} \mu \mathrm{L}^{-1}$, was also determined, as a control.

SDS-PAGE and protein gel blotting: The SF samples (6 $\mu \mathrm{L}$ ) were submitted to SDS-PAGE according to Laemmli (1970) using pH 8.8 in the sample buffer and a 5-10\% polyacrylamide gradient in the resolving gel. Electroblotting of proteins to a nitrocellulose membrane was done essentially as described by Towbin et al. (1979), using a Bio-Rad Trans-Blot semi-dry transfer cell. Blotted proteins were visualized by staining with $2 \%(\mathrm{w} / \mathrm{v})$ Ponceau S in 3\% (w/v) trichloracetic acid (TCA). Before addition of antibodies, the membranes were incubated with $6 \%(\mathrm{w} / \mathrm{v})$ defatted milk in PBST (PBS plus $0.1 \%(\mathrm{v} / \mathrm{v})$ Tween 20), for $1 \mathrm{~h}$. The blots were probed with rabbit antienterolobin serum (1:1000 dilution in PBST) whose specificity has been tested as described elsewhere (Lima et al., 1999). Cross-reacting enterolobin was detected using goat anti-rabbit IgG conjugated to horseradish peroxidase (1:3000 dilution in PBST) and revealed using diaminobenzidine (DAB) $(10 \mathrm{mg}$ per $33 \mathrm{~mL})$ and $0.03 \%(\mathrm{v} /$ v) $\mathrm{H}_{2} \mathrm{O}_{2}$. 


\section{RESULTS}

The presence of enterolobin and hemolytic activity was assessed in 32 different soluble fractions (SF) that were prepared from maturing, mature, germinating and post-germinated seeds. The electrophoretic profiles of the SF samples are presented in Figure 1. For all samples, the most intense bands were observed approximately in the molecular mass range between 45 and $75 \mathrm{kDa}$. The intensity of these bands increased sharply from SF1 to SF4 (early maturing seeds), followed by a gradual increase from SF4 to SF 12 and 13 (mature seeds), when a maximum was observed. Then, protein concentration steadily decreased down to SF32.

The immunodetection of enterolobin monomer and oligomers in the soluble fractions is displayed in Figure 2. Enterolobin monomer was detected in all samples except SF1 and SF2, corresponding to maturing seeds of approximately 14 and 11 weeks before complete maturation, respectively. Enterolobin dimer was found from SF6 to SF24 (from approximately seven weeks before maturation until two days following germination), and the trimer was unequivocally present from SF8 (approximately four weeks before maturation) to SF16 (half average germination time). Higher association forms (HAF) of enterolobin were mainly observed in SF12 (mature seeds) to SF16. Figure 2 also presents the association forms detected for pure enterolobin $(10 \mu \mathrm{g})$, used as positive control.

Figures 3 and 4 (see legend for details) present the hemolytic activity and enterolobin association forms observed in SF from different stages of $E$. contortisiliquum seeds. Figure 3 displays the results for maturing seeds at different stages in terms of weeks before maturation (SF1 to 11) and for mature seeds (SF12 and 13). The bars represent SF grouped considering the same hemolytic titer and the same degree of association of enterolobin (monomer-M, dimer- D and trimer- T). Similarly, Figure 4 presents the results referent to germinating and post-germinating seeds (SF 14 to 32). The bars were also grouped according to the experimental designed sequence, using the same criteria as in Figure 3. In the legend of Figure 3 was mentioned the hemolytic titer determined for a solution of pure enterolobin $(0.5 \mu \mathrm{g}$ $\mu \mathrm{L}^{-1}$ in $0.15 \mathrm{~mol} \mathrm{~L}^{-1} \mathrm{NaCl}$ ), for comparison.

All SF displayed hemolytic activity but in SF 1, 2, 3, 31 and SF 32 the activity was not prevented by preincubation at $65^{\circ} \mathrm{C}$. Therefore, the hemolytic titer was determined just for fractions from nine weeks before maturation, mature seeds and post-germinated seeds until $8 \mathrm{~d}$ after germination (SF4 to 30). Enterolobin hemolytic activity increased during seed maturation and the highest hemolytic titers (32) were found in mature and germinating seeds until $21.2 \mathrm{~h}$ of germination (SF16),

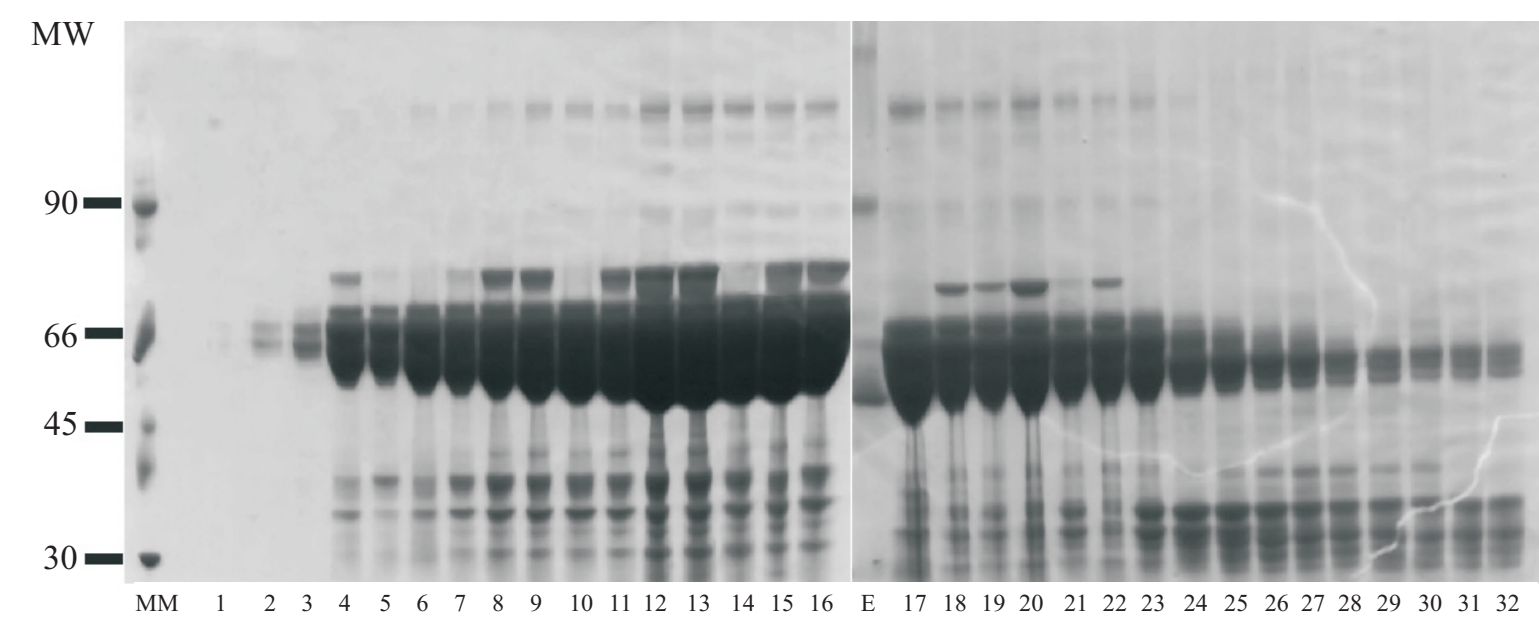

Figure 1. SDS-PAGE (5-10\% gradient) profile of E. contortisiliquum seeds at different phases. Samples of $6 \mu \mathrm{L}$ of maturing, mature, germinating and post-germinated seed soluble fractions (SF). The gel was stained with Coomassie Brilliant Blue. MW: Molecular mass of marker proteins (kDa). The lane number corresponds to the SF number. Lanes: $\mathbf{1}$ to 11 - maturing seeds; 12 and 13 - mature seeds; 14 to 21 - germinating seeds. 22 - recently germinated seeds and 23 to 32 - post-germinated seeds. Refer to text for detailed identification of SF samples. 


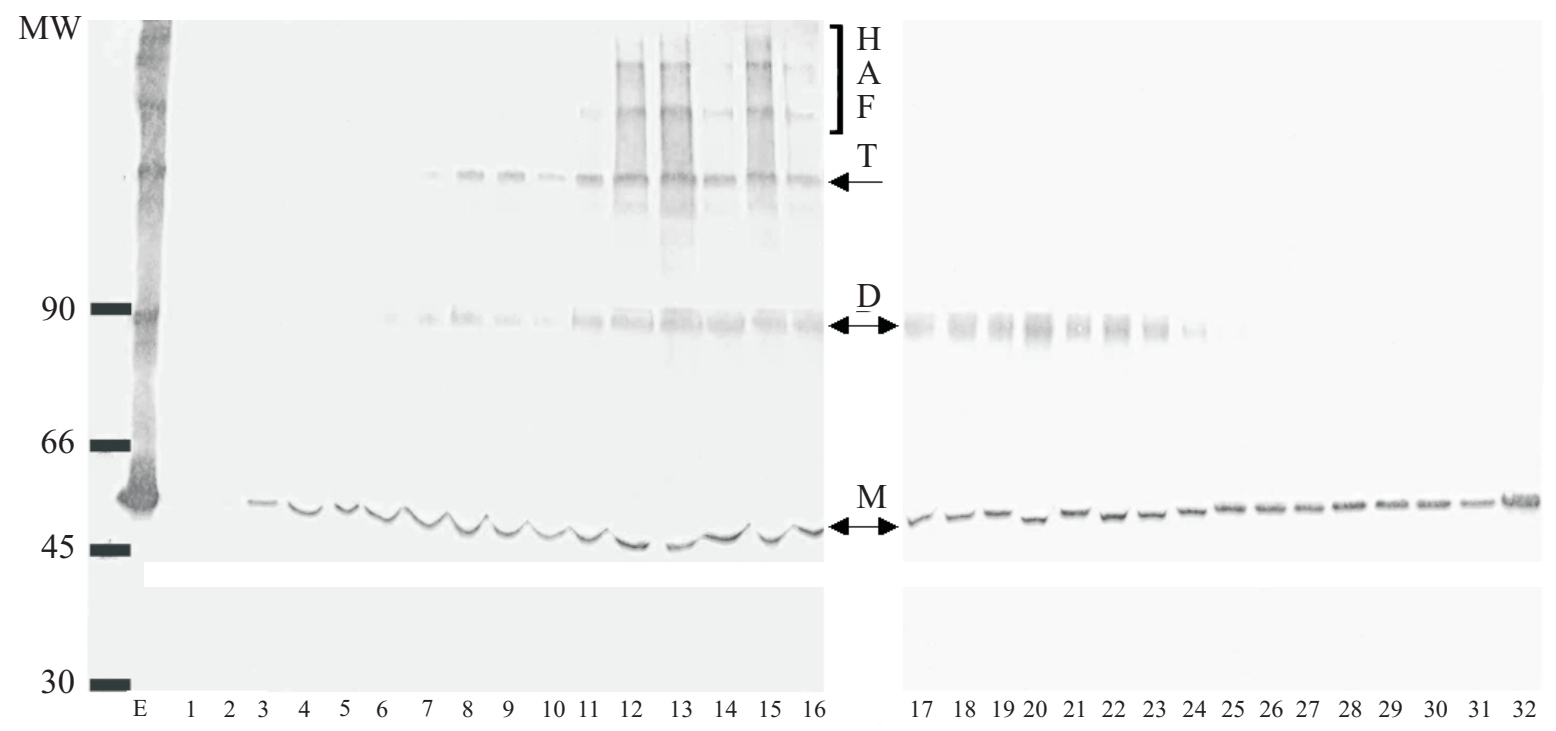

Figure 2. Immunodetection of enterolobin in E. contortisiliquum seeds in the different phases investigated. Samples of $6 \mu \mathrm{L}$ of maturing, mature, germinating and post-germinated seed soluble fractions (SF) were subjected to SDS-PAGE (as described in Figure 1), electrotransferred to a nitrocellulose membrane followed by enterolobin immunodetection. Rabbit anti-serum anti-enterolobin (1:1000 dilution) was used as first antibody and goat anti-rabbit IgG conjugated with horseradish peroxidase (1:3000 dilution) as second antibody. The blot was developed with DAB using $\mathrm{H}_{2} \mathrm{O}_{2}$ as substrate. $\mathbf{E}$ indicates enterolobin $(10 \mu \mathrm{g}), \mathbf{M}=$ monomer, $\mathbf{D}=$ dimer, $\mathbf{T}=$ trimer, and $\mathbf{H A F}=$ higher association forms (above trimer level) of enterolobin. The numbers identify the SF. Lanes 1 to 11 - maturing seeds; 12 and 13 - mature seeds; 14 to 21 - germinating seeds; 22 - recent germinated seeds; 23 to 32 - post-germinated seeds obtained as described in material and methods.

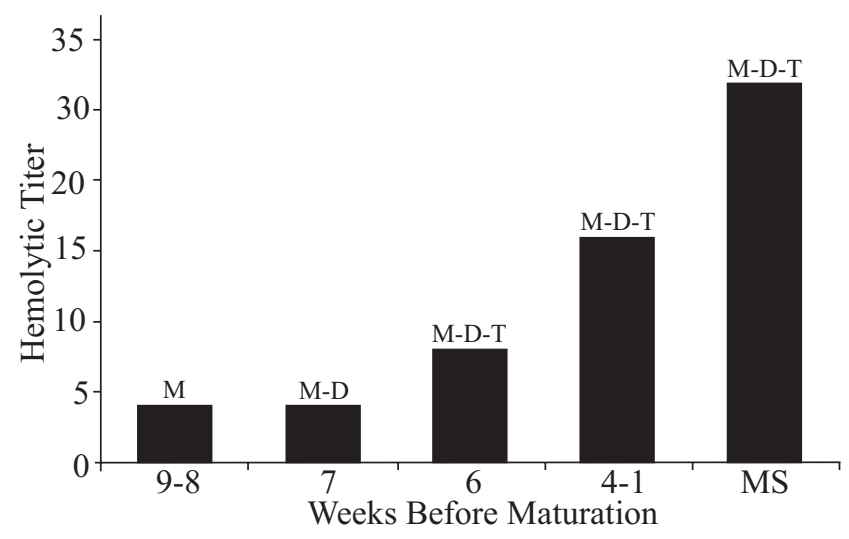

Figure 3. Bar graph displaying the hemolytic activity titer and the degree of association found in soluble fractions (SF) from maturing (9-8 wk before maturation) to mature seeds (MS). The abscissa values represent the SF of seeds in terms of weeks before maturation, from maturing (9-8 wk before maturation) to MS, grouped according to the enterolobin degree of association and hemolytic titer. $\mathbf{M}=$ monomer, $\mathbf{D}=$ dimer, and $\mathbf{T}=$ trimer. The hemolytic titer of a solution of pure enterolobin $\left(0.5 \mu \mathrm{g} \mu \mathrm{L}^{-1}\right)$ was 128 , for comparison. corresponding to half of the average E. contortisiliquum germination time. After that, the titer decreased exponentially until a titer of 2 was reached $(8 \mathrm{~d}$ after germination).

\section{DISCUSSION}

The operational classification of enterolobin as a cytolytic protein is essentially based on the hemolytic activity method used for its detection and should not be directly extrapolated to explain the physiological functions of this protein. However, the remarkable enterolobin toxic activities, e.g. cytolytic, cytotoxic, insecticidal and inflammatory (Sousa and Morhy, 1989; Sousa et al., 1990, 1993; Fontes et al., 1997) strongly indicate that it could act as a defense protein in $E$. contortisiliquum seeds, although the existence of other in vivo roles such as a reserve protein cannot be ruled out. By monitoring the expression of enterolobin during seed maturation and germination our aim was to test whether enterolobin behaved like other seed proteins with well established functions. 


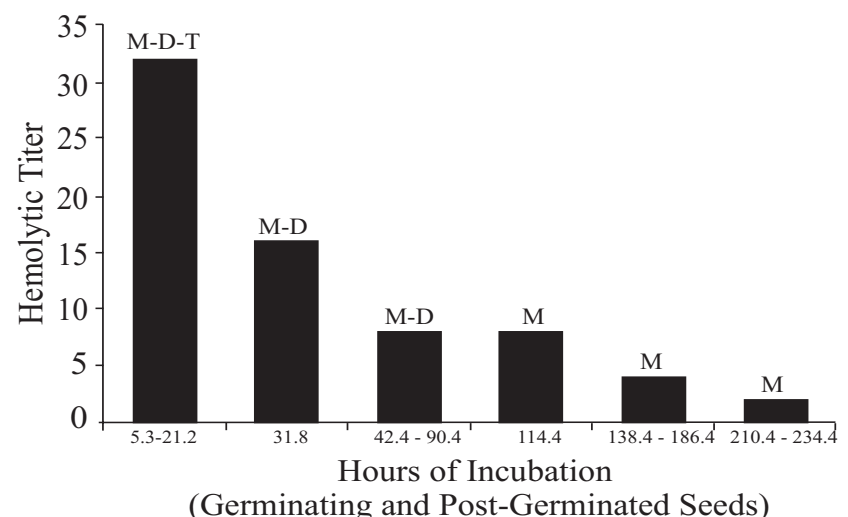

Figure 4. Bar graph displaying the hemolytic activity titer and the degree of association found in SF from germinating (incubation time from 5.3 to $42.4 \mathrm{~h}$ ) and post-germinated seeds (incubation time from 66.4 to $234.4 \mathrm{~h}$ ), grouped as described in the legend of Figure 3. $\mathbf{M}=$ monomer, $\mathbf{D}=$ dimer, and $\mathbf{T}=$ trimer.

In this work a novel experimental design for gathering the seed samples was introduced. The strategy used in the harvest of germinating and post-germinated seeds was based on the average germinating time and aimed to minimize the intrinsic natural dispersion due to the lack of synchronism of the germinative process of seeds in nature.

It has been described that protein concentration increases in maturing seeds (Bewley and Black, 1994). Similarly, the SDS-PAGE protein profile indicated an increase in protein content during maturation, reaching the highest levels in mature seeds. The results also showed that the protein content decreased as germinative and post- germinative processes occurred.

The enterolobin monomer was detected in all developmental phases, except in samples from the earliest maturing seeds analyzed (SF1 and 2), in which the total protein content and concentration is low (Figures 1 and 2 ), probably because of the immaturity and degree of hydration of the seeds (data not shown). So, it could be that the content of enterolobin in these SF was below the sensitivity of detection of the method used, in the range of $80 \mathrm{ng}$, as determined (data not shown). Interestingly, despite the differences in the amount of oligomeric association forms present in samples from SF3 to SF32, the relative amount of the monomeric species apparently presented no significant alteration.
With reference to hemolytic activity analysis, the possibility that other(s) factor(s), like saponins (Assa et al., 1973) could be interfering with the observed results cannot be overlooked. Control assays were carried out using samples preheated at $65^{\circ} \mathrm{C}$ for $30 \mathrm{~min}$, a condition that inactivates enterolobin hemolytic activity, but not saponins. This procedure allowed us to ascertain whether the hemolytic activity was due mainly to enterolobin or not. In addition, the possibility of unequal concentrations and/or activity of these factors in the different SF tested must be considered. It was possible to identify samples where other factors besides enterolobin were clearly contributing to the hemolysis.

Although SF1, 2 and 3 presented hemolytic activity, it was not determined how much of it was due to enterolobin. However, from SF4 to SF30 (which comprises maturing, mature, germinating and post-germinated seeds) it was possible to observe hemolysis mainly due to enterolobin. The hemolytic activity assays could not indicate whether there was an increase in enterolobin content or activity during seed development or both. It was observed that the hemolytic titer reached a maximum in mature seeds and up to half the average germination time. The presence of high enterolobin activity could be important considering that seeds at these stages can be subject to intense attack by predators, such as insects and larvae. In germinating seeds after $0.5 \mathrm{t}_{\mathrm{m}}$ and in postgerminated samples, the hemolytic activity was relatively low. This decrease in enterolobin content may have been influenced by seed size changes, for instance, due to the growth of embryonic axis and hydration, which take place during the developmental seed phases studied.

The detection of enterolobin dimer, trimer and higher association forms were found in the SF that presented the highest protein content, noticeably in mature and early germinating seeds. It could also be observed that the higher the organization degree, the greater the hemolytic titer. This observation is in agreement with the possible enterolobin cytolysis mechanism, based on that of aerolysin, which involves association of the monomers into heptameric complexes that form pores in the cell membrane (Sousa et al., 1994; Rossjohn et al., 1998; Lima, 1999).

Enterolobin does not appear to act as a reserve 
protein, considering that there was no detectable change in enterolobin monomer intensity in almost all stages studied. Besides, no enterolobin processing seemed to have occurred, since the molecular mass of the monomer was virtually the same in all SF and no immunodetected fragments were observed, which would be the case if enterolobin had been used as reserve protein (Fincher, 1989; Hershko and Ciechanover, 1992; Vierstra, 1993; Müntz, 1996). Although no enterolobin precursor form could be observed, the possible occurrence of such a precursor in an earlier seed phase cannot be disregarded. Future cloning and sequencing of the enterolobin gene may elucidate if enterolobin suffers any kind of posttranslational proteolytic processing.

Does the presence of enterolobin in different developmental phases of E. contortisiliquum seeds point to a defensive role of this cytolytic protein? No conclusive answer can be made yet. Previous studies with seed defense proteins using plants as different as tomato and wheat revealed an increase in activity and relative concentration of these proteins during seed development (Caruso et al., 1999) and seed germination (Mo and Bewley, 2003). Mo and Bewley (2003) did not observe any decrease in protein activity during germination, in contrast with enterolobin that displayed a decrease in activity after $0.5 \mathrm{t}_{\mathrm{m}}$ of E. contortisiliquum seeds. However, considering that tomato is a "domesticated" species, physiological parameters such as average germination time is not so relevant in this kind of investigation. Therefore, a straightforward comparison between this work and Mo and Bewley's study could not be made. Notwithstanding, further studies, including under stress conditions, should be performed in order to establish the role of enterolobin in vivo. Finally, the unraveling of the physiological role of enterolobin in $E$. contortisiliquum may be important for future expression of this protein in transgenic plants.

Acknowledgements: Authors thank Dr. Fabian Borghetti for the use of the Thermobiology Laboratory, Fábio Nakamura and Renan de Souza Rodrigues for technical assistance and Dr. Patrícia G. B. de Carvalho for critical reading of the English manuscript. We also wish to thank the Brazilian Research Council $(\mathrm{CNPq})$ for financial support.

\section{REFERENCES}

Assa Y, Shani S, Gestener B, Tencer Y, Birk Y, Bondi A (1973) Interaction of alfalfa saponins with components of the erythrocyte membrane in hemolysis. Biochim. Biophys. Acta 307:83-91.

Bewley JD, Black M (1994) Seeds, Physiology of Development and Germination. $2^{\text {nd }}$ edn. Plenum Press, New York.

Bittencourt SET, Silva LP, Azevedo RB, Cunha RB, Lima CMR, Ricart CAO, Sousa MV (2003) The plant cytolytic protein enterolobin assumes a dimeric structure in solution. FEBS Lett. 549:47-51.

Caruso C, Chilosib G, Caporalea C, Leonardia L, Bertinia L, Magrob P, Buonocorea V (1999) Induction of pathogenesis-related proteins in germinating wheat seeds infected with Fusarium culmorum. Plant Sci. 140:107-120.

Cuadrado C, Burbano C, Gelencse E, Pedrosa MM, Ayet G, Muzquiz M, Pusztai A, Hajos G (2000) Influence of germination on lectin in Lens culinares seeds. Acta Alim. 29:231-240.

Fincher GB (1989) Molecular and cellular biology associated with endosperm mobilization in germinating cereal grains. Annu. Rev. Plant Physiol. Plan Mol. Biol. 40:305-346.

Fontes W, Sousa MV, Aragão JB, Morhy L (1997) Determination of the amino acid sequence of the plant cytolysin enterolobin. Arch. Biochem. Biophys. 347:201-207.

Hershko A, Ciechanover A (1992) The ubiquitin system for protein degradation. Annu. Rev. Biochem. 61:761807.

Howard SP, Buckley JT (1985) Activation of the holeforming toxin aerolysin by extracellular processing. J. Bacteriol. 163:336-340.

Laemmli UK (1970) Cleavage of structural proteins during the assembly of the head of bacteriophage T4. Nature 227:680-685.

Lima CMR (1999) Enterolobina: aspectos bioquímicos e fisiológicos. Brasília, University of Brasilia. PhD thesis.

Lima CMR, Borghetti F, Sousa MV (1997) Temperature and germination of the Leguminosae Enterolobium contortisiliquum. Braz. J. Plant Physiol. 9:97-102.

Lima CMR, Grossi MF, Kalume DE, Roepstorff P, Morhy L, Ricart CAO, Sousa MV (1999) Cytosolic and nuclear 
localization of the cytolytic and insecticidal plant protein enterolobin. J. Exp. Bot. 341:1743-1750.

Mo B, Bewley JD (2003) The relationship between Bmannosidase and endo- $\beta$-mannanase activities in tomato seeds during and following germination: a comparison of seed populations and individual seeds. J. Exp. Bot. 54:2503-2510.

Müntz K (1996) Proteases and proteolytic cleavage of storage proteins in developing and germinating dicotyledonous seeds. J. Exp. Bot. 47:605-622.

Muzquiz M, Welham T, Altares P, Goyoaga C, Cuadrado C, Romero C, Guillamon E, Domoney C (2004) The effect of germination on seed trypsin inhibitors in Vicia faba and Cicer arietinum. J. Sci. Food Agric. 84:556-560.

Rossjohn J, Feil SC, McKinstry WJ, Tsernoglou D, van der Goot G; Buckley JT, Parker MW (1998) Aerolysin a paradigm for membrane insertion of beta-sheet protein toxins? J. Struct. Biol. 121:92-100.

Shewry PR, Lucas JA (1997) Plant proteins that confer resistance to pests and pathogens. Adv. Bot. Res. 26:135-192.
Shewry PR (1995) Plant storage proteins. Biol. Rev. 70:375-426.

Sousa MV, Morhy L. (1989) Enterolobin, a hemolytic protein from Enterolobium contortisiliquum (Leguminosae-Mimosoideae). Purification and characterization. An. Acad. Bras. Ciên. 61:405-412.

Sousa MV, Morhy L, Richardson M, Hilder VA, Gatehouse AMR (1993) Effects of the cytolytic seed protein enterolobin on coleopteran and lepidopteran insect larvae. Entomol. Exp. Appl. 69:231-238.

Sousa MV, Ricart CAO, Morhy L (1990) Cytolic proteins and peptides. Ciên. Cult. 42:495-500.

Sousa MV, Richardson M, Fontes W, Morhy L (1994) Homology between the cytolytic seed protein enterolobin and bacterial aerolysins. J. Protein Chem. 13:659-67.

Towbin H, Stahelin T, Gordon J (1979) Electrophoretic transfer of proteins from polyacrylamide gels to nitrocellulose sheets: procedure and some applications. Proc. Natl. Acad. Sci. USA 76:4350-54.

Vierstra RD (1993) Protein degradation in plants. Annu. Rev. Plant Physiol. Plant Mol. Biol. 44:385-410. 